\title{
Evaluation of Landsat Data for Landslide Identification as a Means for Watershed Management
}

\author{
Masamu Aniya*, Masahiro Etaya** \\ Haruhisa Shimoda**
}

\begin{abstract}
Identification of landslides by Landsat MSS digital data was attempted to evaluate the data as a means for watershed management. The maximum likelihood classifier identified about 10 percent of the landslides, which occupied nearly 50 percent of the total landslide area. The threshold size was approximately one-third of the pixel size, or in this case about $2000 \mathrm{~m}^{2}$. If the landslide can be successfully separated from the flood plain, the data may be utilized, based on the area estimate, for computing failed volume and debris discharges in a given area for the management.
\end{abstract}

Keywords: Landsat MSS data, digital processing, landslide, waterhed management, threshold size

\section{概 要：ランドサットデータによる流域管理のための崩壊地識別の評価}

流域管理は崩壊の把握と密接に結びついているので, 山梨県の雨畑川流域, 静岡県の東河内流域とその周辺を対象地域 として, ランドサットMSS ディジタルデータによる崩壊地識別を行った。この地域は, 脆い地質, 急峻な地形, 台風によ る豪雨などの要因が重なり, 現在約 1700 ケ所の崩壊が認められる。空中写真と現地調査から作った崩壊分布図をグランド・ トルースとして，最尤法による分類結果を評価したところ，約 $10 \%$ 崩壊が識別されたことが判った。これらは面積的に は全崩壊地の約 $50 \%$ を占める。この過程で大きな問題となったのは河原との誤分類である。

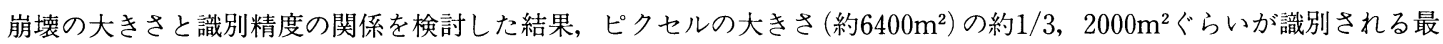
少限であることが判明した。

また大きな崩壊地識別精度が上り，しかも流域管理に大きな影響を与えるので, ある流域内での全崩壊面積, 土量や崩 壊からの土砂流出量の推定などには使える可能性があることが判った。しかしこのためには, 他の地理情報デー夕を使っ て，崩壊地と河原を分離することが前提となる。

\section{INTRODUCTION}

Watershed management is very closely tied to the control of debris discharges, because debris flows often inflict severe damages on human activities in mountainous areas due to intensive land use and frequent intense rainstorms. Catastrophic debris discharges, which cause disasters and drastic environmental changes, are usually associated directly or indirectly with landsliding. Consequently, it is very important to monitor landslides in the watershed management.

* Institute of Geoscience, University of Tsukuba Ibaraki 305

* * Tokai Research and Information Center Tokai University, Tokyo 151

「写真測量とリモートセンシング」vol.24, No.4, 1985
Traditionally, landslide studies and the watershed management have been greatly aided by the use of aerial photographs. At the current level of the techniques, a combination of aerial photographs and field work probably provides the most reliable information for the mountainous areas where accessibility is limited. It requires, however, special skills to interpret landslides and watershed conditions and usually a large number of photographs are involved to cover a large area. For these reasons, there is limitation as to the applicability of the photo interpretation to a large area owing to time and effort required. On this point, the Landsat MSS data may provide a means with which to locate landslides in a large area.

It is the purpose of this study to explore the feasibility of landslide identification with the Landsat MSS data through digital processing, to 
estimate the threshold size of landslide in relation to the pixel size, and to evaluate the data as a means for the watershed management. Although there are few landslide studies using the Landsat MSS data (Sauchyn and Trench, 1978; Sakai et al., 1984, 1985), numerical evaluation of landslide identification has not been previously reported.

\section{STUDY AREA}

The area selected for this study is composed of the Amahata River basin, Higashikochi basin and their vicinities (Fig. 1). The two basins occupy approximately $120 \mathrm{~km}^{2}$. The study area is characterized by frequent landsliding and subsequent debris discharges due to heavy rainfalls mostly brought by typhoons from July through October. Currently there are about 1700 landslides, with their sizes ranging from few hundred to several hundred thousand square meters. Most of them can be classified as planar slide (Crozier, 1973) or debris slide or debris avalanche (Varnes, 1978). The total landslide area is close to $6 \mathrm{~km}^{2}$.

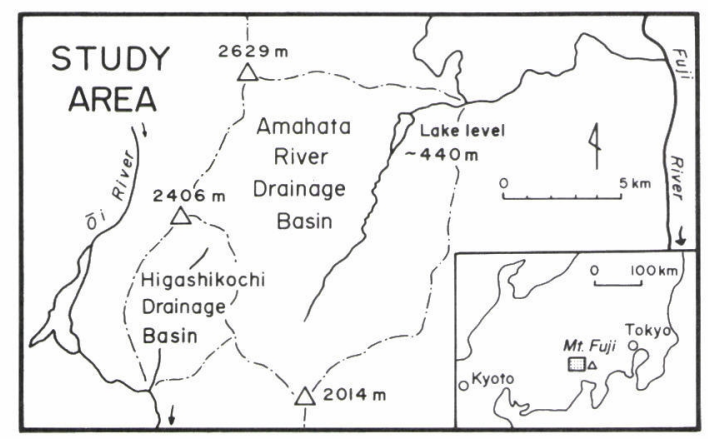

Fig. 1 Location of the study area.

Bedrocks are of Cretaceous and Paleogene ages and are primarily shale, mudstone and sandstone. These rocks, particularly shales, are generally weathered. Geologic conditions coupled with topographic factors of large relief, up to $2300 \mathrm{~m}$ (lowest $310 \mathrm{~m}$ at the Amahata River confluence and highest $2629 \mathrm{~m}$ ), and steep hill slopes (average about $42^{\circ}$ ) strongly favor landsliding. Thickness of regolith ranges up to about $100 \mathrm{~cm}$, but less than $50 \mathrm{~cm}$ is most common. Vegetation is predominantly deciduous below the $1500-1800 \mathrm{~m}$, while conifers dominate at higher elevations. Logging is very active in this area.

\section{METHODOLOGY}

In order to produce landslide distribution maps as the ground truth for Landsat identification, black and white aerial photographs of about 1:16,000 scale taken on May 9, 1979 (Amhata River area), and October, 24, 1980 (Higashikochi area), the latest complete coverage of the areas, were utilized for landslide interpretation. After field-checking these interpreted landslides, the distribution map was compiled at a scale of 1:10,000. As for the Landsat data, that taken on May 22, 1979 (Fig. 2), the closest date to the photographs, was selected. The data are of good quality and geometric and radiometric corrections have been applied. Each pixel was resampled by the nearest neighbor method for a $80 \times 80 \mathrm{~m}$ size and the contrast was stretched to 256 levels for all four bands. Geometry is accurate to within one pixel size.

The maximum likelihood classifier (Fukue et al., 1981) was employed to identify landslides. The

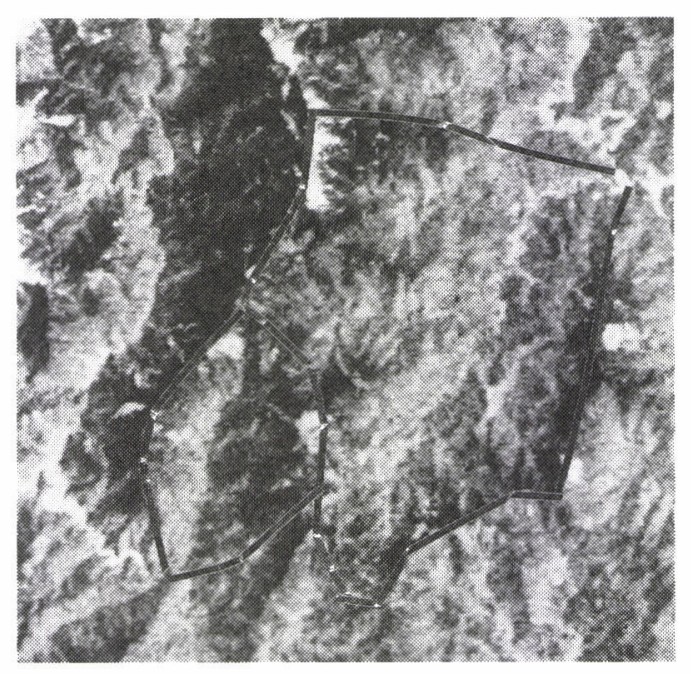

Fig. 2 Landsat MSS and 5 of the study area. 
training areas for class "landslide" were chosen by four aspects (N, E, S and $\mathrm{W})$ and these four constituted subclasses in the subsequent processing to increase the classification accuracy. At the same time, for the purpose of evaluating the performance, classes of water, flood plain, and vegetation (18 subclasses) were also sampled.

\section{RESULTS AND DISCUSSION}

The classification map was output by an inkjet plotter at a scale of 1:25,000. The 1:10,000 landslide map was reduced to $1: 25,000$ on a transparent material for the direct comparison of the results by superimposition. Figure 3 shows a simplified map which indicates only those pixels classified as landslides by the computer processing. For comparison, the distribution of major landslides and streams is illustrated in Figure 4. From these two figures, it can be readily recognized that the clustered areas represent landslides, whereas the linear patterns are actually rivers. These misclassifications occurred because rivers had very extensive flood plains as compared to the size of water body, which made the landcover similar to landslides when viewed at the pixel size. Similarity of the spectral response patterns of landslides and flood plains imposes serious limitations for distin-

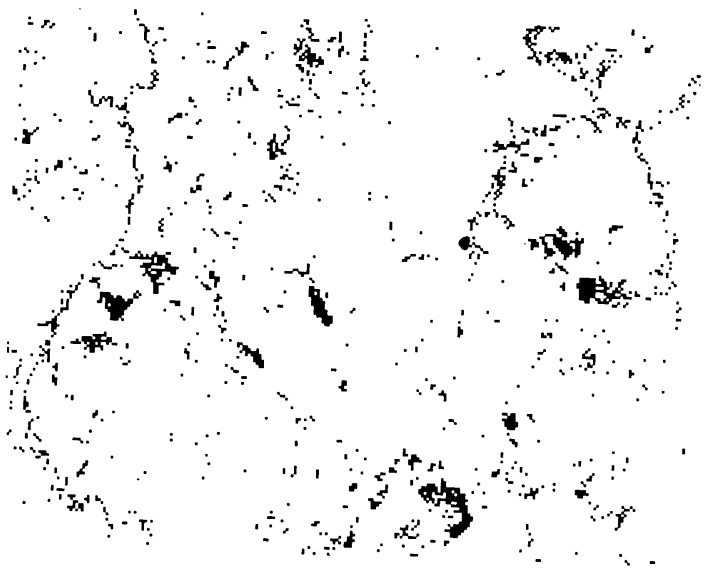

Fig. 3 Map showing pixels classified as landslides.

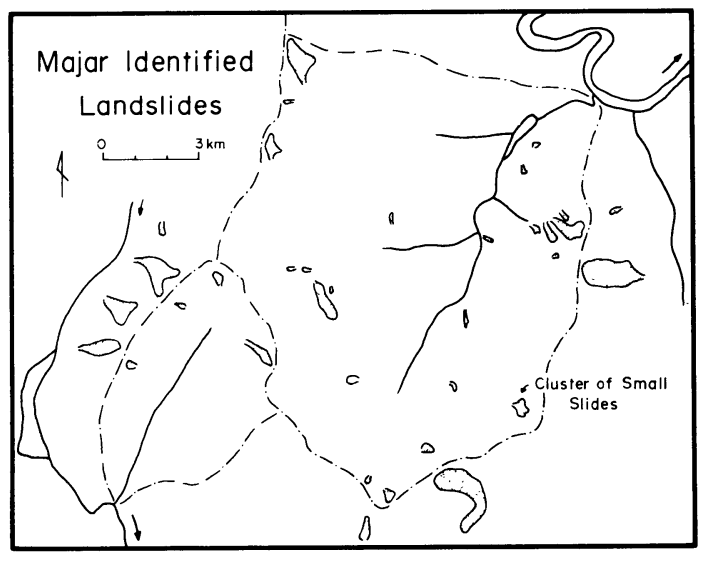

Fig. 4 Distribution of the major landslides and streams.

guishing landslides with spectral signatures alone by digital processing.

Accuracy of the landslide classification was examined by the training areas. It was found that the subclasses of $\mathrm{N}$ - and $\mathrm{W}$-facing had good records of 87 and 95 percent, respectively, whereas $\mathrm{S}$ - and $\mathrm{E}$ facing ones had worse records of 78 and 71 percent, respectively. Close checking with the ground truth map disclosed that some of the latter group were misclassified as "bush in logged area" or "flood plain".

Among about 1700 landslides distributed in the study area, about 93 percent are smaller than $6400 \mathrm{~m}^{2}$ (area of one pixel), and about 85 percent are even smaller than $3200 \mathrm{~m}^{2}$. It was therefore antic ipated that many of the landslides would be overlooked in the classification. Superimposition of the maps revealed that only about 10 percent of the landslides were correctly identified; however, in terms of the area, they represented nearly 50 percent of the total landslide area. The identification rate of large landslides (larger than $6400 \mathrm{~m}^{2}$ ) was nearly 50 percent, whereas only 5 percent of those less than $3200 \mathrm{~m}^{2}$ were identified. It was rather surprising that landslides even as small as $200-300 \mathrm{~m}^{2}$ were sometimes identified. In such cases, however, it was found that several landslides were clustered to form an apparent larger one. Also small landslides along the streams were often identified, indicat- 
ing the influence of the flood plains.

Since the condition of the surrounding landcover, such as dense or sparse vegetation cover, flood plain and/or logged area, strongly influences the identification, it is very difficult to singularly determine the threshold size of the landslide. After checking the percentage of the correct identification by size, it appears that an area of around $2000 \mathrm{~m}^{2}$, or about one-third of the pixel size, is critical. The percentage is relatively high $(22 \%)$ for those landslides larger than $2000 \mathrm{~m}^{2}$ as compared to that for those with less area $(4 \%)$. While the landslides larger than $2000 \mathrm{~m}^{2}$ are 20 percent of the total number, they occupy nearly 80 percent of the total landslide area. Naturally the rate of the correct identification goes up with the increase of the size. For the watershed management, the identification of the large ones is most critical because they supply a large quantity of debris into streams through surface erosion (Tanaka, 1976) even after the failure.

\section{SUMMARY AND CONCLUSION}

Landslide identification by digital processing of the Landsat MSS data was attempted in order to evaluate the data as a means for the watershed management. The ground truth map of the landslide distribution was compiled at a scale of 1:10,000 from aerial photographic interpretation and field surveys. Training areas for landslides in the maximum likelihood classifier were selected based on four aspects. The classified map was output at 1:25,000 scale and the reduced ground truth map was directly overlaied to examine the results.

About 10 percent of the landslides were identified, which occupied nearly 50 percent of the total landslide area. The threshold size for the correct identification is regarded as about $2000 \mathrm{~m}^{2}$, or onethird of the pixel size. Although the overall accuracy of locating landslides in the watersheds is not very good for practical uses, it appears possible to obtain a reasonable estimate of the total landslide area because large ones can be well identified. Also, when estimating the area of a landslide by the number of pixels and the pixel size, there is a tendency to overestimate, which would compensate for the fewer number of landslides correctly identified. Therefore, the Landsat MSS data may be a feasible means for the watershed management, when it is concerned with the estimation of the failed volume (Aniya, 1985b), and the prediction of debris discharges into streams. The computation is based on the total area of the landslides in a given region.

In order to obtain an estimate of the total landslide area from the number of pixels, however, it is critical to distinguish flood plains from landslides using ancillary data. Since the landslides in this area typically have slope gradients ranging between 35 and 50 degrees (Aniya, 1985a), and the flood plain is almost level, it appears best to utilize the digital terrain model (DTM) for computing the gradient of a pixel, which is then used as the criteria for the discrimination.

Acknowledgment: partial support by Grant in Aid for the Research in Environmental Sciences from the Ministry of Education, Science and Culture (Project No. 58030016) is gratefully acknowledged.

\section{REFERENCES}

Aniya, M. 1985a. Landslide susceptibility mapping in the Amahata River Basin, Japan. Annals of the Association of American Geographers, 75: 102114.

Aniya, M. 1985b (in press). Contemporary erosion rate by landsliding in Amahata River Basin, Japan. Zeitschrift für Geomorphologie.

Crozier, M. J. 1973. Techniques for the morphometric analysis of landslips. Zeitschrift für Geomorphologie, 17: 78-101.

Fukue, K., Shimoda, H., and Sakata, T. 1981. Table look-up maximum likelihood method. Journal of the Japan Society of Photogrammetry and Remote Sensing, 20(2): 14-22. (in Japanese with English abstract)

Sakai, T., Nishikawa, H., Fukuyama, S., and 
Sugimura, T. 1984. A study on landslide using Landsat MSS data. Proceedings, 4th Japanese conference on remote sensing, Tokyo. pp.173174. (in Japaniese)

Sakai, T., Nishikawa, H., Fukuyama, S., and Sugimura, T. 1985. A study of landslides in Hayakawa watershed by using Landsat MSS data--Detection of new landslides. Journal of the Remote Sensing Society of Japan, 5: 5-15. (in Japanese with English abstract)

Sauchyn, D. J., and Trench, N. R. 1978. Landsat applied to landslide mapping. Photogrammetric Engineering and Remote Sensing, 44: 735-741.

Tanaka, M. 1976. Rate of erosion in the Tanzawa Mountains, central Japan. Geografiska Annaler, 58A: 155-163.

Varnes, D. J. 1978. Slope movement--types and processes. In R. L. Schuster and R. J. Krizek, eds. Landslide: analysis and control. Washington, $\mathrm{D}$. C., Highway Research Board Special Report 176: 11-33.

ニュース

(財)リモート・センシング技術センター創立10周年記念講演会

1.日時：1985年11月25日(月) $13: 30 \sim 17: 30$

2. 場 所：経団連ホール 千代田区大手町 $1-9-4$ 経団連会館 $14 \mathrm{~F}$

3. 講 演 内 容: 1) 日本の地球観測衛生について

宇宙開発事業団 人工衛星開発本部総括開発部員 石澤禎弘

2 ) 米国ランドサット計画の民営化について（仮題）

EOSAT 社（米国） 社長 C. P. Williams

3 ）リモートセンシング技術10年の歩み（RESTEC の活動を中心に）

(財)リモートセンシング技術センター 技術参与 小平信彦

5. 問い合わせ先 : 港区六本木 $7-15-17$ 二ニ六本木ビル

(財)リモートセンシング技術センター

Tel 03(403) 1761 